\title{
Bacitracin Induces Sphere Formation in Halobacterium Species which Lack a Wall Peptidoglycan
}

\author{
By M. F. MESCHER AND J. L. STROMINGER \\ The Biological Laboratories, Harvard University, \\ Cambridge, Massachusetts 02138, U.S.A.
}

(Received 27 January 1975; revised 23 April 1975)

\begin{abstract}
Bacteria of the genus Halobacterium lack the peptidoglycan layer characteristic of the walls of most prokaryotic organisms (Larsen, 1967). The major carbohydrate-containing component of the envelope of $H$. salinarium is a high molecular weight glycoprotein (Mescher, Strominger \& Watson, 1974) which may play a role in maintaining the structural integrity of the envelope (Mescher et al. 1974). Similar glycoproteins appear to be present in the envelopes of $H$. cutirubrum (unpublished results) and H. halobium (Koncewicz, I972). Conflicting reports have appeared regarding inhibition of the growth of Halobacteria by penicillin G (Cho, Doy \& Mercer, I967; Mohr \& Larsen, 1963), a specific inhibitor of the transpeptidase and carboxypeptidase activities of peptidoglycan synthesis (Strominger, 1970). Since Halobacteria lack peptidoglycan, the ability of Na-penicillin G to inhibit their growth was re-examined. Ampicillin and cephalosporin $\mathrm{C}$, which inhibit these same activities (Gale et al. 1972), were also tested together with several antibiotics which interfere with other steps in the pathway of peptidoglycan synthesis. These included: D-cycloserine, which inhibits the conversion of L-alanine to D-alanine and the formation of D-alanyl-Dalanine (Gale et al. 1972); bacitracin, which inhibits the dephosphorylation of $\mathrm{C}_{55}$-isoprenyl pyrophosphate (Siewert \& Strominger, 1967); and vancomycin, ristocetin (Gale et al. I972; Strominger, I970), moenomycin (Lugtenberg, van Schijndel-van Dam \& van Bellegem, 1971) and janiemycin (Linnett \& Strominger, 1973), all of which appear to inhibit the transfer of the disaccharide-pentapeptide unit from the lipid intermediate to the acceptor.
\end{abstract}

\section{METHODS}

The organisms used were Halobacterium salinarium, strain I (ATCC19700), H. halobium (NRC34003) and H. cutirubrum (NRC3400I). All strains were grown in the liquid medium previously described for growth of $H$. salinarium (Mescher et al. 1974). Growth was measured with a Klett photometer using a red filter. The antibiotics used were obtained from The Squibb Institute for Medical Research, New Brunswick, New Jersey, U.S.A. (Na-penicillin G, ampicillin, janiemycin); Abbot Laboratories, North Chicago, Illinois, U.S.A. (ristocetin); Eli Lilly \& Co., Indianapolis, Indiana, U.S.A. (vancomycin, D-cycloserine, cephalosporin C); The Upjohn Co., Kalamazoo, Michigan, U.S.A. (bacitracin); and Hoechst Pharmaceutical Co., Frankfurt, Germany (moenomycin).

\section{RESULTS AND DISCUSSION}

The concentrations of the antibiotics required to give $50 \%$ inhibition of growth are shown in Table I. All of the antibiotics tested, with one exception, either caused no inhibition at 
Table I. Antibiotic concentrations required to inhibit growth by $50 \%$

Growth inhibition was determined by comparing the extinctions of cultures grown at several concentrations of antibiotic to the extinctions of control cultures (no antibiotic) at the end of exponential phase. Cultures were started using a $5 \%$ inoculum of organisms grown for $36 \mathrm{~h}$ in liquid medium.

\begin{tabular}{|c|c|c|}
\hline \multicolumn{3}{|c|}{$\begin{array}{l}\text { Concentration required for } 50 \% \text { growth inhibition } \\
\qquad(\mu \mathrm{g} / \mathrm{ml})\end{array}$} \\
\hline H. salinarium & H. cutirubrum & H. halobium \\
\hline I 400 & 2025 & I300 \\
\hline 6300 & 6800 & 5400 \\
\hline$>1500$ & $>1500$ & $>$ I 500 \\
\hline 500 & 450 & 650 \\
\hline 150 & 225 & 150 \\
\hline 5 & I & I 2 \\
\hline$>2000$ & $>2000$ & $>2000$ \\
\hline$>2000$ & 1200 & I 200 \\
\hline$>1000$ & $>1000$ & 60 \\
\hline$>1000$ & $>1000$ & $>1000$ \\
\hline
\end{tabular}

* Both isomers of cycloserine may inhibit growth by reacting non-enzymically with pyrodixal phosphate (Roze \& Strominger, 1963). If inhibition by D-cycloserine were specific, as in peptidoglycan synthesis, it would be expected to inhibit growth at lower concentrations than does L-cycloserine.

the maximum concentration tested or caused inhibition at concentrations 100 to ro000 times greater than those required for inhibition of bacteria possessing peptidoglycan. The inhibition observed at these extremely high concentrations was probably non-specific and unrelated to the specific effects of the antibiotics on peptidoglycan synthesis in normal bacteria.

The striking exception was bacitracin, which inhibited the growth of Halobacteria at concentrations comparable to those required for normal bacteria. Further examination of the effect of bacitracin showed that it caused a morphological change in the bacteria. Addition of bacitracin $(30 \mu \mathrm{g} / \mathrm{ml})$ to cultures which had entered the exponential phase of growth decreased the growth rate and growth stopped after approximately one doubling (as measured by a Klett photometer) whereas control cultures without added bacitracin continued to grow for more than two doublings. Cultures were examined by phase contrast microscopy at various times after addition of bacitracin (Fig. I). Organisms in the control culture (no bacitracin) were rod-shaped at all times examined (Fig. I $a$ ). Organisms inhibited by bacitracin gradually changed from the normal rod shape to spherical forms. Complete conversion to spherical forms occurred only after growth in bacitracin for approximately one doubling time (about $30 \mathrm{~h}$ ). Similar results were obtained with both $H$. halobium and $H$. cutirubrum.

While several effects of bacitracin on bacterial membranes have been reported (Weinberg, 1967), Storm \& Strominger (1973, 1974) have clearly shown that it specifically forms a complex with the $\mathrm{C}_{55}$-isoprenyl pyrophosphate, thus inhibiting peptidoglycan synthesis, and have strongly suggested that this is its primary effect in the inhibition of bacterial growth. The low concentration of bacitracin required to inhibit Halobacteria and its effect on their morphology suggest that it may act by inhibiting the synthesis of a structural component of their envelope. There is now considerable evidence that the synthesis of at least some of the glycoproteins in eukaryotic organisms involves polyisoprenol phosphate intermediates (Behrens, 1974). Moreover, preliminary results suggest that the synthesis of the $H$. salinarium envelope glycoprotein also involves a polyisoprenyl pyrophosphate-linked intermediate, and bacitracin may therefore inhibit growth of Halobacteria and cause 


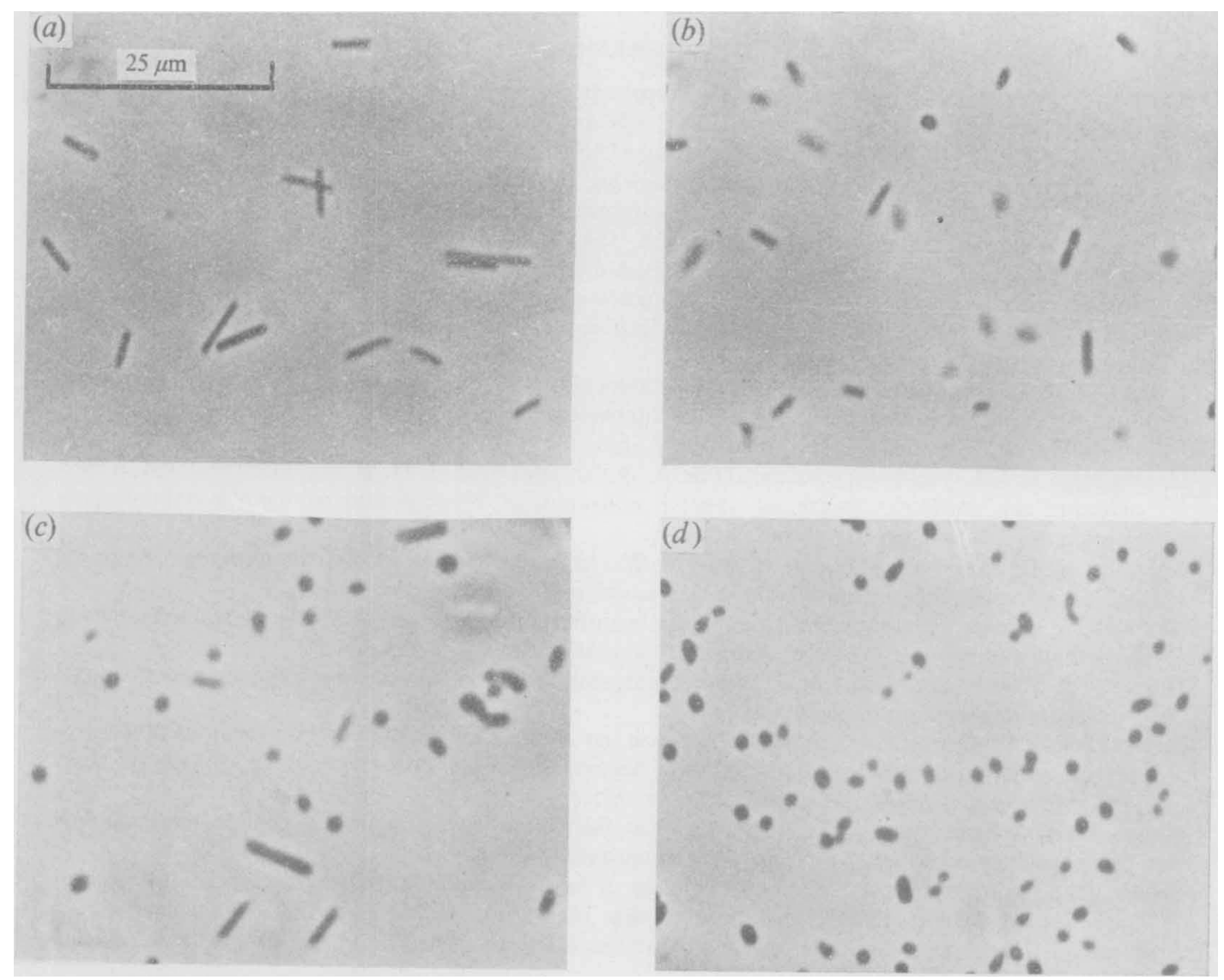

Fig. I. Phase-contrast photomicrographs of normal and bacitracin-inhibited cultures. (a) Control culture. Bacteria appeared identical at all times, and therefore only one photograph (taken $24 \mathrm{~h}$ after inoculation) is shown. $(b),(c),(d)$ Cultures $12.5,24.0$ and $36.5 \mathrm{~h}$ after addition of bacitracin, respectively.

conversion to spherical forms by inhibiting the synthesis of this glycoprotein as a consequence of forming a complex with polyisoprenyl pryophosphate. Bacitracin may also alter the lipid composition of the membrane to some extent by inhibiting synthesis of saturated isoprenoid chains of the type known to be present in at least one of the lipids of H. cutirubrum (Kates, Yengoyan \& Sastry, I965).

These results show that a number of antibiotics thought specifically to affect peptidoglycan synthesis at several different points in the biosynthetic pathway do not inhibit the growth of Halobacteria. An exception to this rule is bacitracin; the morphological changes which accompany growth inhibition and the nature of the components of the Halobacteria envelope suggest that the mode of action of bacitracin in inhibiting these bacteria may to some extent be similar to its mode of action in bacteria possessing peptidoglycan.

This investigation was supported by research grants from the U.S. Public Health Service (AM-13230) and from the National Science Foundation (GB-29747). 


\section{REFERENCES}

BEHRENS, N. H. (I974). Polyprenol sugars and glycoprotein synthesis. In Biology and Chemistry of Eucaryotic Cell Surfaces, pp. 159-I80. Edited by E. Y. C. Lee and E. E. Smith. New York: Academic Press.

Cho, K. Y., Doy, C. H. \& Mercer, E. H. (1967). Ultrastructure of the obligate halophilic bacterium Halobacterium halobium. Journal of Bacteriology 94, 196-201.

Gale, E. F., Cundliffe, E., Reynolds, P. E., Richmond, M. H. \& Waring M. J. (i972). The Molecular Basis of Antibiotic Action, pp. 49-1 20. London: John Wiley.

Kates, M., Yengoyan, L. S. \& Sastry, P. S. (1965). A diether analog of phosphotidyl glycerophosphate in Halobacterium cutirubrum. Biochimica et biophysica acta 98, 252-268.

Koncewicz, M. A. (1972). Glycoproteins in the cell envelope of Halobacterium halobium. Biochemical Journal 128, $124 \mathrm{P}$.

LARSEN, H. (1967). Biochemical aspects of extreme halophilism. Advances in Microbial Physiology 1, 97-1 32.

Linnett, P. E. \& Strominger, J. L. (1973). Additional antibiotic inhibitors of peptidoglycan synthesis. Antimicrobial Agents and Chemotherapy 4, 23I-236.

Lugtenberg, E. J. J., van Schijndel-van Dam, A. \& Van Bellegem, T. H. M. (1971). In vivo and in vitro action of new antibiotics interfering with the utilization of $N$-acetyl-glucosamine- $N$-acetyl-muramylpeptide. Journal of Bacteriology 108, 20-29.

Mescher, M. F., Strominger, J. L. \& Watson, S. W. (I974). Protein and carbohydrate composition of the cell envelope of Halobacterium salinarium. Journal of Bacteriology 120, 945-954.

MoHr, V. \& LARSEN, H. (1963). On the structural transformation and lysis of Halobacterium salinarium in hypotonic and isotonic solutions. Journal of General Microbiology 3r, 267-280.

Roze, U. \& STRominger, J. L. (I963). The non-enzymatic reaction between D-cycloserine and pyridoxal phosphate. Federation Proceedings 22465.

Siewert, G. \& Strominger, J. L. (I967). Bacitracin, an inhibitor of the dephosphorylation of lipid pyrophosphate, an intermediate in biosynthesis of bacterial cell walls. Proceedings of the National Academy of Sciences of the United States of America 57, 767-773.

Storm, D. R. \& Strominger, J. L. (1973). Complex formation between bacitracin peptides and isoprenyl pyrophosphates. Journal of Biological Chemistry 248, 3940-3945.

Storm, D. R. \& Strominger, J. L. (I974). Binding of bacitracin to cells and protoplasts of Micrococcus lysodeikticus. Journal of Biological Chemistry 249, I823-1827.

Strominger, J. L. (1970). Penicillin-sensitive enzymatic reactions in bacterial cell wall synthesis. Hariey Lectures 64, 179-213.

Weinberg, E. D. (1967). Bacitracin. In Antibiotics, vol. I, pp. 90-10 I. Edited by D. Gottlieb and P. D. Shaw. New York: Springer-Verlag. 